\title{
Pembelajaran Problem Solving Modifikasi untuk Meningkatkan Kemampuan Pemahaman Konsep Matematis Siswa SMP
}

\author{
Fahrudin ${ }^{1}$, Netriwati ${ }^{1}$, Rizki Wahyu Yunian Putra ${ }^{1}$ \\ ${ }^{1}$ Universitas Islam Negeri Raden Intan Lampung. Jalan Endro Suratmin, Sukarame, Bandar \\ Lampung 35133, Indonesia. \\ *Corresponding Author. E-mail: fahrulsusanto86@gmail.com
}

Received : 28-05-2018; Revised : 30-05-2018; Accepted : 31-05-2018

\begin{abstract}
Abstrak
Tujuan dari penelitian ini adalah untuk mengetahui peningkatan kemampuan pemahaman konsep matematis dengan pembelajaran problem solving modifikasi lebih baik dibandingkan kemampuan pemahaman konsep matematis dengan pembelajaran konvensional. Penelitian ini merupakan penelitian kuantitatif jenis eksperimen semu. Uji hipotesis yang digunakan dalam penelitian ini yaitu uji $-\mathrm{t}$. Hasil dari penelitian menunjukkan bahwa peningkatan kemampuan pemahaman konsep matematis siswa menggunakan pembelajaran problem solving modifikasi lebih baik daripada kemampuan pemahaman konsep matematis menggunakan pembelajaran konvensional.

Kata Kunci: Kemampuan Pemahaman Konsep Matematis, Pembelajaran Problem Solving Modifikasi
\end{abstract}

\begin{abstract}
The purpose of this study is to determine the improvement of the ability to understand mathematical concepts with problem-solving learning modification better than the ability to understand mathematical concepts with conventional learning. This research is a quantitative research type of quasi-experiment. Hypothesis test used in this research is $t$-test. The result of research indicates that the improvement of students' mathematical concept comprehension ability using problem-solving learning modification is better than the ability to understand mathematical concept using conventional learning.
\end{abstract}

Keywords: Ability to Understand Mathematical Concept, Learning Problem Solving Modification

\section{PENDAHULUAN}

Kemampuan pemahaman konsep sangat penting bagi peserta didik, karena konsep matematika yang satu dengan yang lain saling berkaitan sehingga untuk mempelajarinya harus runtun dan berkesinambungan (Farida, 2015; Haryani, 2017). Namun kenyataannya kemampuan pemahanan konsep peserta didik masih belum menggembirakan. Kondisi ini didukung oleh pernyataan yang diungkapkan oleh penelitian sebelumnya bahwa tingkat pemahaman konsep peserta didik masih sangat rendah. Tidak hanya peserta didik di sekolah, permasalahan kemampuan pemahaman konsep matematis juga terjadi pada mahasiswa seperti yang telah dijelaskan oleh (Sudarman \& Vahlia, 2016; Karim, 2013). Permasalahan ini disebabkan oleh model pembelajaran yang kurang tepat dalam pembelajaran matemati (Netriwati, 2016; Purwasih, 2015; Yusri, 2015). Diduga pembelajaran problem solving modifikasi mampu mengatasi permasalahan pada kemampuan pemahaman konsep matematis. 
Berdasarkan uraian diatas dapat diketahui bahwa perlu ditingkatkan lagi kemampuan pemahaman konsep matematis siswa agar semua siswa mempunyai pemahaman yang baik akan materi yang sudah diajarkan dan tidak mudah untuk melupakan rumus yang sudah diajarkan sebelumnya. Sehingga semua siswa akan dapat mengerjakan berbagai jenis soal baik dari yang mudah, sedang, maupun susah.

Hasil dari penelitian sebelumnya mengungkapkan bahwa pembelajaran problem solving dapat meningkatkan hasil belajar (Bernadeta, Junaidi, \& Okianna, 2015). Selain itu penelitian lainnya menghasilkan bahwa pembelajaran problem solving dapat meningkatkan kemampuan berfikir kritis dan prestasi belajar siswa (Lilih, Budi Utami, \& Haryono, 2016). Kemudian penelitian selanjutnya didapat bahwa pembelajaran problem solving dapat meningkatkan aktifitas dan hasil belajar siswa (Mayang Saputri, Mugiadi, \& Muncarno, 2014). Sedangkan penelitian berikutnya mengungkapkan bahwa ada pengaruh pembelajaran menggunakan model problem solving terhadap hasil belajar aspek pengetahuan dan keterampilan (Naning, Ashadi, \& Muhammad Masykuri, 2016).

Penelitian berikutnya mengungkapkan bahwa model pembelajaran problem solving dapat meningkatkan hasil belajar IPA siswa kelas V (Pri Subekti, 2017). Penelitian lainnya menjelaskan bahwa penggunaan pembelajaran problem solving berpengaruh terhadap kemampuan berfikir kritis siswa (Satrio Wicaksono Sudarman, \& Ira Vahlia, 2014). Kemudian penelitian berikutnya memperoleh bahwa penerapan model pembelajaran problem solving dengan strategi peta konsep dapat meningkatkan minat dan prestasi belajar siswa (Heri Setyoko, Sri Mulyani, \& Ira Vahlia, 2017). Penelitian lainnya mengungkapkan bahwa pembelajaran dengan metode problem solving dapat meningkatkan prestasi belajar siswa (Priswanto, 2016). Kemudian penelitian berikutnya menjelaskan bahwa ada pengaruh penerapan metode problem solving terhadap hasil belajar siswa (Fitria Istiqoma, \& Amir Rusdi, 2015). Berdasarkan pembahasan diatas dapat disimpulkan bahwa perbedaan penelitian ini dengan penelitian sebelumnya yaitu dalam penelitian ini pembelajaran problem solving modifikasi digunakan untuk meningkatkan kemampuan pemahaman konsep matematis siswa.

Hasil penelitian lainnya menunjukkan bahwa kemampuan pemahaman konsep matematis siswa dalam pembelajaran matematika secara keseluruhan berada pada kategori baik (Siti Mawaddah, \& ratih Maryanti, 2016). Penelitian berikutnya diperoleh bahwa kemampuan pemahaman konsep matematis siswa dengan model pembelajaran quantum teaching lebih baik daripada pembelajaran konvensional (Angga Murizal, Yarman, \& Yerizon, 2013). Kemudian penelitian lainnya mengungkapkan bahwa kemampuan pemahaman konsep matematis mahasiswa yang 
memperoleh pembelajaran quantum learning lebih tinggi dari pada mahasiswa yang memperoleh pembelajaran konvensional (Satrio Wicaksono Sudarman, \& Ira Vahlia, 2016).

Penelitian lainnya juga menunjukkan bahwa terdapat perbedaan peningkatan pemahaman konsep dan kompetensi strategis matematis antar siswa yang memperoleh pembelajaran dengan pendekatan metaphorical thinking (Afrillianto, 2013). Sedangkan penelitian lainnya didapat bahwa ada pengaruh metode pembelajaran learning stars with a question terhadap kemampuan pemahaman konsep matematis mahasiswa (Eka Fitri Puspita Sari, 2016). Penelitian berikutnya mengungkapkan bahwa kemampuan pemahaman konsep matematis dan pemecahan masalah berada dalam kategori baik (Lisna Agustina, 2016). Penelitian lainnya menjelaskan bahwa penggunaan model pembelajaran inkuiri terbimbing dapat meningkatkan kemampuan pemahaman konsep matematis (Aguta Sari Sumaryati, \& Dwi Uswatun Hasanah, 2015). Berdasarkan pembahasan diatas dapat disimpulkan bahwa perbedaan penelitian ini dengan penelitian sebelumnya yaitu dalam penelitian ini untuk meningkatkan kemampuan pemahaman konsep matematis menggunakan pembelajaran problem solving modifikasi.

Berdasarkan

penelitian sebelumnya yang telah dipaparkan di atas, maka dalam penelitian ini peneliti tertarik melakukan sebuah penelitian menggunakan pembelajaran problem solving untuk mengatasi permasalahan kemampuan pemahaman konsep matematis siswa. Dalam penelitian ini pembelajaran problem solving disinergikan dengan model pembelajaran yang lain atau dapat dikatakan pembelajaran problem solving modifikasi.

Penelitian ini akan berbeda dengan penelitian sebelumnya dimana pembelajaran problem solving digunakan untuk meningkatkan kemampuan pemahaman konsep matematis. Selain itu, pembelajaran problem solving disinergikan dengan sebuah metode pembelajaran yang lain., Disini peneliti melakukan modifikasi pada langkah-langkah pembelajaran problem solving yaitu dengan menambahkan langkah pembelajaran baru dalam pembelajaran problem solving itu sendiri. Adapun langkah pembelajaran tersebut adalah siswa membuat peta konsep atau rangkuman dari materi yang sedang diajarkan sesuai dengan kemampuan pemahaman konsep mereka masing-masing. Adapun tujuannya yaitu untuk melihat peningkatan kemampuan pemahaman konsep matematis dengan pembelajaran problem solving modifikasi lebih baik daripada kemampuan pemahaman konsep matematis dengan pembelajaran konvensional.

\section{METODE PENELITIAN}

Peningkatan kemampuan pemahaman konsep matematis siswa dalam penelitian ini, kita dapat menghitung peningkatan kemampuan pemahaman konsep matematis siswa 
dengan rumus gain ternormalisasi $(\mathrm{N}-$ gain) seperti berikut ini:

$$
<g>=\frac{\text { Skor }_{\text {posttest }}-\text { Skor }_{\text {pretest }}}{\text { Skor }_{\text {ideal }}-\text { Skor }_{\text {pretest }}}
$$

Dalam penelitian ini, penulis menggunakan metode penelitian eksperimen karena penulis akan mencari perbedaan treatment (perlakuan) tertentu. Jenis metode eksperimen yang digunakan adalah Quasy Experimental Design. Desain dalam penelitian ini yaitu desain kelompok control non-ekivalen. Adapun desain penelitian ini berbentuk seperti Tabel 1. berikut ini:

\section{Tabel 1. Desain Penelitian}

\begin{tabular}{ccccc}
\hline & Group & Pretes & Variabel & Postes \\
$R$ & Eksperimen & $\mathrm{X}_{1}$ & $\mathrm{Y}_{1}$ & $\mathrm{Z}_{1}$ \\
$R$ & Kontrol & $\mathrm{X}_{2}$ & $\mathrm{Y}_{2}$ & $\mathrm{Z}_{2}$ \\
\hline
\end{tabular}

Keterangan:

$R$ : Random

$X_{1}$ : Hasil pretest kelompok eksperimen

$X_{2}$ : Hasil pretest kelompok kontrol

$Y_{1}$ : Perlakuan dengan model pembelajaran Problem Solving modifikasi

$Y_{2}$ : Perlakuan dengan model pembelajaran konvensional

$Z_{1}$ : Hasil post-test kelompok eksperimen

$Z_{2}$ : Hasil post-test kelompok kontro Teknik sampling yang digunakan adalah metode Probability Sampling dengan tekik Cluster Random Sampling. Instrumen yang digunakan dalam penelitian ini adalah instrumen tes (tes kemampuan pemahaman konsep matamatis). Asumsi analisis data yang digunakan yaitu uji normalitas dan uji homogenitas. Teknik analisis data dalam pengujian hipotesis menggunakan $u j i-t$. Adapun pengujian uji normalitas dapat menggunakan uji Liliefors dengan rumus sebagai berikut:

$$
\begin{aligned}
& L_{\text {hitung }}=\max \left|F\left(Z_{i}\right)-S\left(Z_{i}\right)\right| \\
& \text { dengan } L_{\text {tabel }}=L_{(\alpha, n)}
\end{aligned}
$$

Langkah-langkah uji liliefors yaitu sebagai berikut:

1. Mengurutkan data

2. Menentukan frekuensi masingmasing data

3. Menentukan frekuensi kumulatif

4. Menentukan nilai $Z$ dimana

$$
\begin{aligned}
& Z_{i}=\frac{\left(x_{i}-\bar{x}\right)}{s}, \quad \text { dengan } \quad \bar{x}=\frac{\sum x_{i}}{n}, \\
& S=\sqrt{\frac{\sum\left(x_{i}-\bar{x}\right)^{2}}{n-1}}
\end{aligned}
$$

5. Menentukan nilai $f(z)$, dengan menggunakan tabel $\mathrm{z}$

6. Menentukan $S(z)=\frac{f_{k u m}}{n}$

7. Menentukan nilai $L=$ $\left|F\left(Z_{i}\right)-S\left(Z_{i}\right)\right|$

8. Menentukan nilai $L_{\text {hitung }}=$ $\max \left|F\left(Z_{i}\right)-S\left(Z_{i}\right)\right|$

9. Menentukan nilai $L_{\text {tabel }}=L_{(\alpha, n)}$

10. Membandingkan $L_{\text {tabel }}$ dan $L_{\text {hitung, }}$ serta membuat kesimpulan. Jika $L_{\text {hitung }} \leq L_{\text {tabel }}$, maka $H_{0}$ diterima.

Dengan hipotesis:

$H_{0}$ : data mengikuti sebaran normal

$H_{1}$ : data tidak mengikuti sebaran normal

Uji homogenitas dapat dicari dengan menggunakan uji kesamaan 2 varians dengan rumus:

$H_{1}$ : Ada pengaruh varians 1 dan varians 2

$H_{0}$ : Tidak ada pengaruh antara varians 1 dan varians 2

Dengan rumus $F_{\text {hitung }}$ :

$$
F=\frac{\text { Varians Terbesar }}{\text { Varians Terkecil }}
$$

dengan taraf signifikan $\alpha=0,05$. Sedangkan mencari $F_{\text {tabel }}$ :

$$
F_{\text {tabel }}=F_{\frac{1}{2 \alpha}}
$$

Dengan pengujian $H_{0}$ jika $F_{\text {hitung }} \leq$

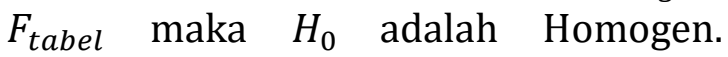


Desimal, 1 (2), 2018 - 185

Fahrudin, Netriwati, Rizki Wahyu Yunian Putra

Sedangkan untuk mencari uji-t digunakan rumus sebagai berikut:

$$
t_{\text {hitung }}=\frac{\bar{X} 1-\bar{X} 2}{\sqrt{\frac{\left(n_{1}-1\right) s_{1}^{2}+\left(n_{2}-1\right) s_{1}^{2}}{n_{1}+n_{2}-2}\left(\frac{1}{n_{1}}+\frac{1}{n_{2}}\right)}}
$$

Keterangan:

$\bar{X}_{1}=$ Nilai rata-rata kemampuan pemahaman konsep matematis kelas eksperimen

$\bar{X}_{2}=$ Nilai rata-rata kemampuan pemahaman konsep matematis kelas kontrol

$n_{1}=$ Banyaknya peserta didik kelas eksperimen

$n_{2}=$ Banyaknya peserta didik kelas kontrol

$s_{1}^{2}=$ Varians data kelompok eksperimen

$s_{2}^{2}=$ Varians data kelompok kontrol

Adapun langkah-langkah pengujian hipotesis ini sebagai berikut:

$H_{o}$ : Kemampuan Pemahaman konsep dengan pembelajaran problem solving modifikasi tidak lebih baik daripada pembelajaran konvensional

$H_{1}$ : Kemampuan Pemahaman konsep dengan pembelajaran problem solving modifikasi lebih baik daripada pembelajaran konvensional.

Dengan Kriteria Uji:

Jika $\left|t_{\text {hitung }}\right| \leq t_{\text {tabel }}$, maka $H_{0 \text { diterima }}$

(Uji Satu Pihak)

HASIL DAN PEMBAHASAN

$\begin{array}{ccr}\text { Hasil } & \text { dari } & \text { Penerapan } \\ \text { problem } & \text { solving }\end{array}$
pembelajaran problem solving modifikasi dan konvensional diterima dengan baik oleh siswa karena pada dasarnya siswa mempunyai kemampuan matematika yang baik. Namun terbatasnya frekuensi peneliti dalam menerapkan pembelajaran problem solving modifikas dikelas eksperimen maka pengaruh penggunaan pembelajaran problem solving modifikas tampak kurang signifikan pada pencapaian kemampuan kognitif siswa. Selain itu fakta yang ditemukan peneliti yaitu mengingat bahwa siswa dituntut untuk dapat menemukan atau memecahkan permasalahan yang diberikan oleh guru, sehingga siswa akan lebih memahami materi dan tidak mudah lupa materi yang sudah diajarkan sebelumnya.

Setelah data kemampuan pemahaman Konsep matematis peserta didik terkumpul baik dari kedua kelas eksperimen maupun dari kelas kontrol diperoleh maka diperoleh:

Tabel 2. Deskripsi Data Kemampuan Pemahaman Konsep Matematis

\begin{tabular}{lllccc}
\hline \multicolumn{1}{c}{ Kelas } & $\mathbf{X}_{\text {maks }}$ & $\mathbf{X}_{\text {min }}$ & \multicolumn{3}{c}{ Ukuran Tendensi sentral } \\
& & & $\overline{\boldsymbol{x}}$ & $\mathbf{M e}$ & $\mathbf{M o}$ \\
Eksperimen & 95 & 36 & 69.4333 & 71 & 71 \\
Kontrol & 83 & 38 & 61.9063 & 62 & 62 \\
\hline
\end{tabular}

Setelah dilaksanakan pembelajaran, pada kelas Eksperimen dan Kelas Kontrol dilakukan evaluasi akhir untuk mengetahui kemampuan pemahaman Konsep Matematis peserta didik sebagai pengumpulan data hasil evaluasi akhir diperoleh bahwa pada kelas eksperimen dengan tes soal essai pada kemampuan pemahaman konsep matematis didapat nilai terbesar 95 dan nilai terkecil 36, nilai tengah (Me) 71, nilai terbanyak yang didapat peserta didik (Mo) adalah 71 dan rata-rata nilai peserta didik adalah 69,43. Sedangkan pada kelas Kontrol hasil tes kemampuan pemahaman konsep matematis didapat nilai terbesar 83 dan 
nilai terkecil 38, nilai rata-rata yang diperoleh peserta didik adalah 61,90, dengan Median 62 serta nilai yang sering muncul adalah 62. Berdasarkan hal ini dapat disimpulkan bahwa kemampuan pemahaman konsep peserta didik kelas eksperimen (mendapat pembelajaran problem solving modifikasi) lebih baik dari peserta didik kelas Kontrol (Mendapat metode konvensional)

Selanjutnya dilakukan analisis uji asumsi dengan uji normalitas kemampuan pemahaman konsep matematis siswa pada kelas eksperimen dengan hasil skor kelas eksperimen sebesar 69,43 dengan $\boldsymbol{L}_{\text {hitung }}=\mathbf{0 . 0 9 6 7}$ dan $\boldsymbol{L}_{\text {tabel }}=\mathbf{0 . 1 5 9}$ hal ini menunjukan bahwa $\boldsymbol{L}_{\text {hitung }}<\boldsymbol{L}_{\text {tabel }}$ sehingga dapat disimpulkan data berdistribusi normal. Dan kelas control adalah sekor kelas kontrol sebesar 60,90 dengan $\boldsymbol{L}_{\text {hitung }}=\mathbf{0 . 1 1 2 4}$ dan $\boldsymbol{L}_{\text {tabel }}=$ 0.1542 hal ini menunjukan bahwa $\boldsymbol{L}_{\text {hitung }}<\boldsymbol{L}_{\text {tabel }} \quad$ sehingga dapat disimpulkan data berdistribusi normal. Berikut hasil rekapitulasi perhitungan uji normalitas Pemahaman Konsep matematis pada kelas eksperimen dan kelas kontrol.

Tabel 3. Hasil Perhitungan Uji Normalitas

\begin{tabular}{cccc}
\hline Kelas & $\boldsymbol{L}_{\text {hitung }}\left(L_{(\alpha, n)}\right)$ & $\boldsymbol{L}_{\text {tabel }}$ & Keterangan \\
Eksperimen & 0.0967 & 0.159 & Normal \\
Kontrol & 0.1124 & 0.1542 & Normal \\
\hline
\end{tabular}

Untuk mengetahui apakah kedua

Berdasarkan perhitungan hasil uji coba normalitas Kemampuan Pemahaman Konsep matematis pada kelas eksperimen dan kelas kontrol dengan taraf sigifikansi $\alpha=5 \%$, diperolah bahwa nilai dari $L_{\text {hitung }}$ dari setiap kelompok kurang dari $L_{\text {tabel }}$ sehingga hipotesis nol dari setiap kelompok diterima. Dapat disimpulkan bahwa data yang diperoleh dari setiap kelompok berasal dari populasi yang berdistribusi normal. Uji Kesamaan Dua Varians kemampuan Pemahaman Konsep Matematis skor memiliki karakter yang sama atau berbeda maka diperlukan uji F. pengujian variansi ini yaitu membandingkan varians terbesar dan varians terkecil. Jika $F_{\text {hitung }} \leq F_{\text {tabel }}\left(\sigma_{1}, \sigma_{2}\right) \quad$ didapat dari distribusi dengan peluang $\frac{1}{2} \alpha$ sedangkan derajat kebebasan $\sigma_{1}\left(n_{1}-1\right)$ dan $\sigma_{2}\left(n_{2}-2\right)$ masing-masing sesuai dengan $d k$ pembilang dan $d k$ penyebut. Hasil pengujian varians dengan taraf signifikan $\alpha=5 \%$ dapat dilihat pada Tabel 4 .

Tabel 4. Hasil Perhitungan Uji Kesamaan Dua Varians

\begin{tabular}{ccccc}
\hline Kelas & Varians & $\boldsymbol{F}_{\text {hitung }}$ & $\boldsymbol{F}_{\text {tabel }}$ & Keterangan \\
Eksperimen & 218.599 & 1.81 & 4.001 & Homogen \\
Kontrol & 120.539 & & & \\
\hline
\end{tabular}

Berdasarkan Tabel 4. Hasil Menunjukan bahwa $F_{\text {hitung }}<F_{\text {tabel }}$ perhitungan skor Kemampuan Pemahaman konsep matematis diperoleh $F_{\text {hitung }}=1,81 \quad$ dan $\quad F_{\text {tabel }}=4,001$. dengan hal ini dapat disimpulkan bahwa $H_{0}$ diterima atau sempel berasal dari populasi yang memiliki varians sama. 
Untuk menguji perbedaan Kemampuan Pemahaman konsep matematis peserta didik digunakan rumus uji-t, karena data yang diperoleh berdistribusi normal dan memiliki nilai varians sama, maka rumus yang digunakan sebagai berikut dengan besaran $d k=n_{1}+n_{2}-2$, harga $t_{\text {tabel }}$ dihitung $d k=30+32-2=60$ maka harga $t_{\text {tabel }}=1.67$ dengan taraf signifikansi 5\%. Hasil perhitungan dapat dilihat pada Tabel 5. berikut ini:

Tabel 5. Hasil Perhitungan Uji Hipotesis

\begin{tabular}{ccccc}
\hline Kelas & Rata-Rata $(\boldsymbol{x})$ & $\boldsymbol{t}_{\boldsymbol{t a b e l}}\left(\boldsymbol{t}_{\boldsymbol{a}, \boldsymbol{d} \boldsymbol{b}}\right)$ & $\boldsymbol{t}_{\text {hitung }}$ & Keterangan \\
Eksperimen & 69,4333 & 1.67 & 2.28 & Terima $\mathrm{H}_{0}$ \\
Kontrol & 61,9063 & & & \\
\hline
\end{tabular}

Tabel 6. Hasil Perhitungan Uji N-gain

\begin{tabular}{ccccc}
\hline Kelas & Rata-Rata $(\boldsymbol{x})$ & $\boldsymbol{t}_{\text {tabel }}\left(\boldsymbol{t}_{\boldsymbol{a}, \boldsymbol{d} \boldsymbol{b}}\right)$ & $\boldsymbol{t}_{\text {hitung }}$ & Keterangan \\
$\begin{array}{c}\text { Eksperimen } \\
\text { Kontrol }\end{array}$ & 0.54265 & 1.67 & 3.31 & Terima $\mathrm{H}_{0}$ \\
\hline
\end{tabular}

Berdasarkan Tabel 5. perhitungan diperoleh $\quad t_{\text {hitung }}=2,28 \quad$ dan $t_{\text {tabel }}=1.67$ sehingga $t_{\text {hitung }}>t_{\text {tabel }}$, yang berarti $\mathrm{H}_{0}$ ditolak yang berarti kemampuan pemahaman konsep dengan pembelajaran problem solving modifikasi lebih baik dari pada pembelajaran konvensional. Berdasarkan hal ini dapat disimpulkan bahwa ada pengaruh kepada peserta didik yang mendapat perlakuan pembelajaran problem solving modifikasi.

Berdasarkan Tabel 6. perhitungan diperoleh $\quad t_{\text {hitung }}=3,31 \quad$ dan $t_{\text {tabel }}=2,00$ sehingga $t_{\text {hitung }}>t_{\text {tabel }}$, yang berarti $\mathrm{H}_{0}$ ditolak yang berarti peningkatan kemampuan pemahaman konsep dengan pembelajaran problem solving modifikasi lebih baik dari pada pembelajaran konvensional. Berdasarkan hal ini dapat disimpulkan bahwa terdapat peningkatan kemampuan pemahaman konsep matematis siswa yang mendapat perlakuan pembelajaran problem solving modifikasi. Hal ini disebabkan karena pembelajaran problem solving modifikasi lebih banyak memberikan kesempatan peserta didik untuk belajar sendiri dan memecahkan permasalahan yang diberikan. Permasalahan tersebut dicari sebuah alternatif penyelesaiannya oleh mereka sendiri sehingga ia benar-benar paham materi. Selain itu, siswa membuat peta konsep atau rangkuman materi yang diajarkan. Dengan membuat peta konsep atau rangkuman tersebut siswa akan lebih mudah memahami materi yang sudah diajarkan dan tidak mudah lupa dengan materi yang sudah diajarkan karena mereka sendiri yang membuat peta konsep atau rangkuman di buku mereka masing-masing.

Hasil penelitian ini menunjukkan bahwa peningkatan kemampuan pemahaman konsep matematis dengan pembelajaran problem solving modifikasi lebih baik daripada kemampuan pemahaman konsep matematis dengan pembelajaran konvensional. Hal ini terbukti dalam penelitian sebelumnya menjelaskan bahwa pembelajaran problem solving dapat meningkatkan hasil belajar (Bernadeta, Junaidi, \& Okianna, 2015). Selain itu penelitian lainnya menghasilkan bahwa pembelajaran problem solving dapat 
meningkatkan kemampuan berfikir kritis dan prestasi belajar siswa (Lilih, Budi Utami, \& Haryono, 2016). Kemudian penelitian selanjutnya didapat bahwa pembelajaran problem solving dapat meningkatkan aktifitas dan hasil belajar siswa (Mayang Saputri, Mugiadi, \& Muncarno, 2014). Sedangkan penelitian berikutnya mengungkapkan bahwa ada pengaruh pembelajaran menggunakan model problem solving terhadap hasil belajar aspek pengetahuan dan keterampilan (Naning, Ashadi, \& Muhammad Masykuri, 2016).

Penelitian

berikutnya

mengungkapkan bahwa model pembelajaran problem solving dapat meningkatkan hasil belajar IPA siswa kelas V (Pri Subekti, 2017). Penelitian lainnya menjelaskan bahwa penggunaan pembelajaran problem solving berpengaruh terhadap kemampuan berfikir kritis siswa (Satrio Wicaksono Sudarman, \& Ira Vahlia, 2014). Kemudian penelitian berikutnya memperoleh bahwa penerapan model pembelajaran problem solving dengan strategi peta konsep dapat meningkatkan minat dan prestasi belajar siswa (Heri Setyoko, Sri Mulyani, \& Ira Vahlia, 2017). Penelitian lainnya mengungkapkan bahwa pembelajaran dengan metode problem solving dapat meningkatkan prestasi belajar siswa (Priswanto, 2016). Kemudian penelitian berikutnya menjelaskan bahwa ada pengaruh penerapan metode problem solving terhadap hasil belajar siswa (Fitria Istiqoma, \& Amir Rusdi, 2015). Dari pembahasan diatas dapat disimpulakan bahwa hasil dari penelitian ini yaitu peningkatan kemampuan pemahaman konsep matematis siswa dengan pembelajaran problem solving modifikasi lebih baik dibandingkan kemampuan pemahaman konsep matematis siswa dengan pembelajaran konvensional.

\section{SIMPULAN DAN SARAN}

Berdasarkan teori dan didukung oleh dengan hasil analisis dan pengolahan data serta mengacu pada perumusan masalah yang telah diuraikan, maka dapat disimpulkan bahwa: terdapat perbedaan kemampuan pemahaman konsep matematis peserta didik dengan penerapan pembelajaran problem solving modifikasi dengan pembelajaran konvensional. Selanjutnya peningkatan kemampuan pemahaman konsep matematis peserta didik

dengan pembelajaran problem solving modifikasi lebih baik daripada metode pembelajaran konvensional.

Berdasarkan kesimpulan penulis menyarankan agar pendidik menggunakan pembelajaran problem solving modifikasi pada pembelajaran matematika untuk meningkatkan Kemampuan Pemahaman Konsep Matematis peserta didik.

\section{DAFTAR PUSTAKA}

Asmah Ahmad, N. S. (2014). Mathematical Problem-Solving Behavior of Sucessful Problem Solvers. Malaysia: Jurnal Sains \& matematik Malaysia, 4(2), 1-13.

Damayanti, H. N., \& Sutama, S. (2016). Efektivitas Flipped Classroom Terhadap Sikap Dan Ketrampilan Belajar Matematika Di Smk. Manajemen Pendidikan, 11(1), 27.

Dona Dinda Pratiwi. (2016). Pembelajaran Learning Cycle 5E berbantuan Geogebra terhadap Kemampuan Pemahaman Konsep Matematis. Al-Jabar: Jurnal Pendidikan Matematika, 7(2), 191202. 
Farida, F. (2015). Mengembangkan Kemampuan Pemahaman Konsep Peserta Didik Melalui Pembelajaran Berbasis VCD. AlJabar: Jurnal Pendidikan Matematika, 6(1), 25-32.

Karim, A. (2013). Penerapan metode penemuan terbimbing dalam pembelajaran matematika untuk meningkatkan pemahaman konsep dan kemampuan berpikir kritis siswa sekolah dasar. Jurnal Pendidikan. 4(2), 198-207.

Masykur, R., Nofrizal, N., \& Syazali, M. (2017). Pengembangan Media Pembelajaran Matematika dengan Macromedia Flash. Al-Jabar: Jurnal Pendidikan Matematika, 8(2), 177-186.

Murizal, A. (2012). Pemahaman Konsep Matematis dan Model Pembelajaran Quantum Teaching. Jurnal Pendidikan Matematika, 1(1).

Netriwati, N. (2016). Analisis Kemampuan Mahasiswa dalam Pemecahkan Masalah Matematis menurut Teori Polya. Al-Jabar: Jurnal Pendidikan Matematika, 7(2), 181-190.

Patnani, M. (2015). Upaya Meningkatkan Kemampuan Problem Solving Pada Mahasiswa. Journal Psikogenesis, 1(2), 130-142.

Purwasih, R. (2015). Peningkatan Kemampuan Pemahaman Matematis dan Self Confidence Siswa MTS di Kota Cimahi Melalui Model Pembelajaran Inkuiri Terbimbing. Didaktik, 9(1), 16-25. Rahman, A., Armiati, A., Akmil, A., \& Rizal, Y. (2015). Implementasi Ctl Dalam Meningkatkan Pemahaman Konsep Matematika Siswa. Jurnal Pendidikan Matematika, 1, 24-29.

Ramadhani Dwi Purwanti., Dona Dinda Pratiwi., \&Achi Rinaldi. (2016). Pengaruh Pembelajaran Berbatuan Geogebra terhadap Pemahaman
Konsep Matematis ditinjau dari Gaya Kognitif. Al-Jabar: Jurnal Pendidikan Matematika, 7(1) , 115122.

Ristiasari, T., Priyono, B., \& Sukaesih, S. (2012). Model pembelajaran problem solving dengan mind mapping terhadap kemampuan berpikir kritis siswa. Journal of Biology Education, 1(3).

Ruseffendi, E.T. (2005). Dasar-dasar Penelitian Pendidikan \& Bidang Non-Eksakta Lainnya. Bandung: Tarsito.

Sudarman, S. W., \& Vahlia, I. (2016). Efektifitas Penggunaan Metode Pembelajaran Quantum Learning terhadap Kemampuan Pemahaman Konsep Matematis Mahasiswa. Al-Jabar: Jurnal Pendidikan Matematika, 7(2), 275-282.

Suhendri, H. (2015). Pengaruh Metode Pembelajaran Problem Solving terhadap Hasil Belajar Matematika Ditinjau dari Kemandirian Belajar. Formatif: Jurnal Ilmiah Pendidikan MIPA, 3(2).

Syazali, M. (2015). Pengaruh Model Pembelajaran Creative Problem Solving Berbantuan Media Maple 11 Terhadap Kemampuan Pemecahan Masalah Matematis. Al-Jabar: Jurnal Pendidikan Matematika, 6(1), 91-98.

Widyastuti, R. (2015). Proses Berpikir Siswa dalam Menyelesaikan Masalah Matematika berdasarkan Teori Polya ditinjau dari Adversity Quotient Tipe Climber. Al-Jabar: Jurnal Pendidikan Matematika, 6(2), 183-194. 